Jurnal Ilmu Sosial Volume 19 | Issue 1 | June 2020 | Page 22-39

Available online at JIS website: https://jis.undip.ac.id

Research Article

\title{
Youthizen Political Literacy: Educating The Generation $Z$
}

Received: $25^{\text {th }}$ June 2019; Revised: $23^{\text {th }}$ January 2020;

Accepted: $28^{\text {th }}$ January 2020; Available online: $31^{\text {th }}$ January 2020

\author{
Nuriyatul Lailiyah", Ghozian Aulia Pradhana ${ }^{2}$, Muchammad Yuliyanto' \\ ${ }^{1}$ Department of Communication, Faculty of Social and Political Sciences, Universitas \\ Diponegoro, J1. Prof. H. Soedarto SH Tembalang, Semarang, 1269, Indonesia \\ ${ }^{2}$ Department of Media and Communication Studies, Faculty of Arts and Social Sciences, \\ Universiti Malaya, Jalan Universiti Kuala Lumpur, 50603, Malaysia
}

\begin{abstract}
This study aims to investigate the differences in attitudes of young generation in showing their political expression on social media before and after the socialization in community service. The issue is related to the attitude of young generation in using social media as a means of expression. Meanwhile, we realize that the internet can often be misleading with the abundance of information and hoaxes. It requires the user's ability to choose and filter the correct and useful information. As the generation that dominates social media and the internet, Generation $Z$ is also a target of politicians and political issues on the internet. Therefore, political literacy for young generation in the internet is crucial. The data in this research were collected by quantitative descriptive methods through surveys before and after the socialization of social media and politics. The survey was conducted on 100 high school students in Semarang City. The results showed that the program for political literacy socialization increased the political literacy of the high school students by providing a positive knowledge regarding politics. The results showed that the program increased the high school students' political literacy and attitude towards the use of social media for political expression.
\end{abstract}

Keywords: Generation Z; Political literacy; Politics; Socialization; Social media

How to Cite: Lailiyah, N., Pradhana, G. A., Yuliyanto, M. (2020). Youthizen Political Literacy: Educating The Generation Z. Jurnal Ilmu Sosial, 19 (1): 22-39 (doi: 10.14710/jis.19.1.2020.2239), [Online]

Permalink/DOI: https://doi.org/10.14710/jis.19.1.2020.22-39

Corresponding Author: n.lailiyah@gmail.com (Nuriyatul Lailiyah) 


\section{INTRODUCTION}

The generation theory (Howe \& Strauss, 1991) suggests that there are five generations known to date, namely: 1. Baby Boomer Generation, born in 1946-1964; 2. Generation X, born in 1965-1980; 3. Generation Y, born in 1981-1994; 4. Generation Z, born in 1995-2010, also called iGeneration, Generation Net, or Generation of the Internet, born from Generation X and Generation Y. And 5. Generation Alpha, born in 2011-2025. Generation Z is the latest generation born after 1994, and before 2004, and now have grown into teenagers. They were born and raised in the digital age, with various sophisticated technologies, such as laptops, mobile phones, Ipads, PDA, MP3 player, BBM, internet, and other electronic devices. Since childhood, they have been familiar with those gadgets. One of Generation $\mathrm{Z}$ features that can be easily identified is the high capacity to access and accommodate the information which provides the opportunities to develop themselves. Many Generation $\mathrm{Z}$ is no longer physically involved with their peers. They tend to communicate through cyberspace (Lailiyah, Yuliyanto, and Pradhana, 2018). Facing the highly tech-savvy Generation Z, it is ideal to understand the plus-minus side of this generation (Howe \& Strauss, 1991).

Furthermore, Generation $\mathrm{Z}$ is highly curious. When confronted with technology, they do not need to be taught. Generation Z, by themselves, will try to master what is needed or what to do to understand and operate a technology (Howe \& Nadler, 2012). Their other distinctive characteristic is multitasking; accustomed to various activities at once; being able to read, talk, watch, or listen to music, all at the same time. This generation has a deep concern towards the environment and politics. Therefore, if this generation acquires a proper education, they would be greatly useful for society, including for themselves.

On the other hand, according to Bennet and Maton in their journal entitled Beyond the 'Digital Natives' Debate towards A More Nuanced Understanding of Students' Technology Experiences, Generation $\mathrm{Z}$ is characterized as impatient, and eager to solve problems immediately due to their habit of communicating and solving problems through a fast and practical cyberspace. (Bennet, S. \& Maton, K., 2010). Some of these generations are lack of skill at verbal communication that can lead them to be ignorant with the environment. If this can be appropriately handled by both the education and work environment, it is likely to have a positive impact.

The high concern characteristic of Generation $\mathrm{Z}$ for the environment and politics can be an advantage for the Indonesian people in applying the principles of democracy. The emergence of choices marked by the rise of political parties compared to the New Order era makes teenagers 


\section{Jurnal Ilmu Sosial Volume 19 | Issue 1| June 2020 | Page 22-39}

should be the focus of political education in every line, both in education and the early regeneration of political parties themselves. One of the most striking examples is the establishment of the Indonesian Solidarity Party (PSI) which was established by Grace Natalie - a youth-dominated party with an antithetical spirit against the interests of other established political parties that have been in power for years. This tendency is considered natural, considering that in 2030, Indonesia will experience a demographic bonus by the explosion of productive age.

Currently, Generation $Z$ becomes the centre of attention in the political studies in Indonesia. This generation is analogous to the two blades. If they lack proper education and guidance from parents and educators, this generation will harm the environment. For example, they are contributing to the dissemination of hoaxes, especially political hoaxes on the internet. On one side, their creative spirit is high, but on the other, it tends to be used for negative purpose. This can happen if they lack education and awareness (Lailiyah, Yuliyanto, and Pradhana, 2018). The literacy on the political issues spread across the internet - in line with the Generation $Z$ habits that are close to the practical and instant online media - raise the importance of political literacy among them. This is intended so that Generation $\mathrm{Z}$ can be utilized as a potential voter for future political interests. Research related to social media found that the profiles on social media are constructed by the account owner (Lailiyah 2016). Therefore, there will be a tendency for the netizen to be manipulated by the framing or information on social media.

If we look closely, Generation Z could provide benefits to political parties if political education input is given intensively towards them. Young people will have a high and increasingly critical awareness of the ongoing political process. The purpose of this study examines their political expression and understanding of social media before and after the socialization.

Understanding and having political awareness is essential for citizens. The progress of the state often depends on the quality of its politics. To get qualified politicians in managing government organizations in a region or state requires public awareness to choose a leader who has integrity and is committed to fighting for the fate of their community. Moreover, the community need to engage in government oversight to conform to achieve people's welfare. The people, including the young generation, have the same duty to engage in the implementation and realization of a people-centred government.

Knowledge and attitude are likely to change after the socialization. In this context, socialization is similar to persuasion. The socialization was aimed to change the youthizen's knowledge and attitude towards politics on social media. In regards to the effect of persuasion, Petty and Cacioppo suggest the Elaboration Likelihood Model of persuasion. 


\section{Jurnal Ilmu Sosial Volume 19 | Issue 1| June 2020 | Page 22-39}

A persuasion theory is a theory that predicts when and how people could be persuaded or not by a piece of information. This theory explains the various ways people evaluate information received. There are two routes in processing information that is used based on the ability and motivation to process information, namely the central route and peripheral route. When people process information through the central route, people become active and critical. Meanwhile, the peripheral route is used to process information. When people have low motivation, people tend to use the peripheral route to process information. Motivation includes the involvement, diversity of arguments, and the predisposition of individuals with critical thinking (Littlejohn \& Foss, 2008: 73-75).

Elaboration Likelihood Model (ELM) is an approach to understanding the persuasion process that describes the decision-making pathway to beliefs, attitudes, and behavioural changes. The central route is when consumers have high involvement in processing information. The peripheral route is when consumers have low involvement in processing information. When there is movement through a high-involvement hierarchy, consumers analyze messages received cautiously and compare them to consumer positions. When the communication response tends to produce some cognitive responses, the central sign refers to ideas and supporting data that directly show the quality of arguments developed in the message. As consumers move through a lowinvolvement hierarchy, cognitive responses tend to be minimal. It is because consumers do not consider the pros and cons of the issue carefully. Peripheral persuasion cues include factors such as attraction and resource expertise or communicators. Lastly, the arguments are presented, and the positive or negative stimuli shape the context in which the message is delivered (e.g., pleasant music, resource attraction, reliability of sources). The effect of truth will arise if something is repeated numerous times, and people will eventually believe it (Mowen \& Minor, 2002:360).

The enabled route depends on the level of elaboration that the recipient has (the relevant thinking about the issue). First, the central route, where the outcome of persuasive effort is a result of deep thought of the recipient of the message on the relevant material issues (e.g., message argument); when the central route process occurs, the quality or strength of the message argument tends to be the key determinant of successful persuasion. Another route of persuasion is peripheral route, where the outcome of persuasion arises from an inferior thought process, e.g., the recipient uses some heuristics (rules of simplification of decisions); for example, the recipient of the message draws a conclusion precisely based on the credibility or fondness of the communicator or based on the reaction of others to the message rather than considering the argument and evidence. These two paths are not an exclusive path, but rather as prototypes that represent 


\section{Jurnal Ilmu Sosial Volume 19 | Issue $1 \mid$ June 2020 | Page 22-39}

extreme elaboration continuity. At the level of intermediate elaboration, central and peripheral routes can work together (O’Keefe, 2008; 2009).

Previous research related to social media and political participation of the young generation in Indonesia has remained scant. One of the research has shown that the young generation at the age of senior high school students is significantly engaged in the use of social media but has very low concern on political issues. They would rather keep their social media clean from the political talks and prefer to discuss political talks offline with their family and close friends (Lailiyah, Yuliyanto, and Pradhana 2018). The engagement of gadget usage from the young generation into their daily life has also shown that the behaviour makes the young generation's life more efficient in an interpersonal communication context. Despite the efficiency, the quality of interpersonal communication that has been mediated by instant messaging is way less than face to face communication. Mediated communication is at risk of being misunderstood (Ayun, 2016).

Another research (Faraon, Stenberg \& Kaipainen, 2014) has shown that Generation Z or youthizen have a tendency not to engage in politics by not discussing politics in their social media. The respondents' negative perceptions of politics made the respondents choose to keep political chats with their families and tended to keep their chats with their peers away from political themes. Not only in cyberspace, but also in social media. Respondents chose to keep their social media clean from political issues.

Social media itself is commonly used in campaigns. Whether commercial marketing campaigns, social marketing campaigns, as well as political campaigns. In regards to the use of social media in political campaigns, the researcher finds some relevant research articles in international journals.

The first research we noted here is an election-related study in India. Lok Sabha's choice differs from previous elections in independent Indian history, and one of the differences is the use of media for electoral purposes. In India, there will be approximately 149 million beginner voters in 2014. With the ease of technology, social media has changed the way people communicate with each other. In previous years, traditional media played an important role in the relationships between people. However, the media became a valuable marketing tool that not only widely known but also helped the people. Politicians are becoming increasingly active in social media. The social media encourage the youth to vote in the 2014 election and help to change the election game. In their research journal entitled "The Influence of Social Media on Voting Behaviour", Roy, Ingle, and Biswas (2014) explain that the phenomenon of social networking has emerged in the last decade. At that time, social networking sites have grown from niche to mass 


\section{Jurnal Ilmu Sosial Volume 19 | Issue 1| June 2020 | Page 22-39}

online activities. Tens of millions of internet users are involved, both in their spare time and at work. However, there are only a few research on the socio-economic impact of the site in the Indian context. The impact of these social networking sites on Indian youth is equally positive and negative.

A phenomenon similar to the case of India also occurs in Malaysia with the involvement of Generation Y in politics and the role of social media. Generation Y is also called as millennium generation. Through research conducted by Shiratuddin, Sani, Hassan, and Ahmad (2016), Generation Y prioritized social media through traditional media, such as print media and broadcast media that gave them space to engage with the kingdom as well as rebels. Study of Political Participation and Social Media Generation in Malaysia was conducted by survey method by collecting 1,029 respondents aged 15 to 25 years. Overall, this study shows that Generation $\mathrm{Y}$ is doubted with new media but also believes that it is the best medium to connect with Malaysian royalty. The role of social media and the young generation of Malaysia is at the highest point in the political world at that time.

The role of online media and social media on attitudes and behavior can be found in research by Faraon, Stenberg, and Kaipainen (2014) entitled Political Campaigning 2.0: The Influence of Online News and Social Networking Sites on Attitudes and Behavior. To distinguish online news (e.g., the New York Times) and social networking sites (e.g., Facebook and Twitter) regarding the attitudes in political campaigns, web-based experiments, campaigns, voting, and elections between two fictional candidates are simulated. The participants' explicit and implicit attitudes and behavior are measured using the Implicit Association Test (IAT). Information derived from online news has a significant influence on explicit and implicit attitudes, while social networking sites are not. Overall, negative information has a stronger impact than positive ones, especially in online news compared to social media. Negative information from both types of media is significant and as a result, also changes its output.

The practical implications of the findings and limitations of this study are looking at the influence of political news in online media and social media and its effects on the young generation. In the case of India, social networking is equally positive and negative - similar to the findings in Malaysia and the United States. Social media is considered as a media that has a strong influence on political choice but is also considered a vital medium in the young generation consideration. The assumption was allegedly due to negative issues and false news that grew on the young generation.

The study contributes to new findings on the effectiveness of online news and social networking sites in political campaigns. Social networking sites are considered by many to be the 


\section{Jurnal Ilmu Sosial Volume 19 | Issue 1| June 2020 | Page 22-39}

'big thing' in political campaigns to influence people's attitudes and ultimately gather people. However, the data shows that participants have scepticism towards social networking sites, and their attitude was not influenced by information spreading through these sources. On the contrary, information from online news influenced their implicit and explicit attitudes. These results suggest that online news issued by journalistic products still holds a strong position in the dissemination of political information.

Furthermore, the results reveal the significance of negative information in the media towards voter's attitudes and behaviour. In particular, negative news from online news sites and social networks are considered more powerful than positive ones. Those who receive negative information from both types of media are more likely to change their explicit attitudes in a negative direction and, as a result, also change their choice. In conclusion, social networking sites have shown their usefulness as a means of mobilization in various protests and the distribution of information viruses. Nevertheless, they have not found their role in political campaigns.

Social media and political literacy are vital to be skilled by the young generation since the political hoaxes, and provocative information on social media are widely spread. Some research discussed the massive political hoaxes on social media during national political campaigns (Hasfi, Usmand, and Santosa, 2017; Santosa, Hasfi, and Lukmantoro, 2018 ). Another research showed the participation of social media users in online political discussions. The varying degrees of anonymity employed by citizens affect their political participation. Besides, anonymity can be understood as citizens' mechanism for coping with various possible consequences, such as legal and social retribution in the personal and professional context (Perbawani and Anshari, 2018). Research has also shown that online political participation via Twitter in Indonesia tends to be degradative to the process of democracy. The conclusion was based on the findings of the use of majority religious value (Islam) as a legitimacy tool for representing ideal (ethical) political leadership and in contrast the use of minority religion values/beliefs to constructing bad political leadership. This implies how religious hegemony is used systematically to acquire political power. (Hasfi, 2017).

This study is different from the studies mentioned above. The novelty of this research focuses on the role of social media in the political literacy of the senior high school student in Semarang City. In this study, political literacy is not merely interpreted in the context of elections. However, it is also related to all political messages passing through social media. This research sought to understand how socialization affects student perception and attitude related to political literacy and the use of social media in a political context. 


\section{Jurnal Ilmu Sosial Volume 19 | Issue 1| June 2020 | Page 22-39}

The survey that had been done before and after the socialization also set a difference compared to the previous studies. The pre and post-socialization surveys were expected to contribute to experimental research, particularly on social media and political literacy.

\section{RESEARCH METHOD}

This research was conducted using a quantitative descriptive method. The purpose of descriptive research is to look briefly at an object, and the right subject is researched. Data were collected through the survey to conduct observations where indicators of variables are the answers to the questions given to respondents. The answers may either in oral or in writing form acquired from the senior high school students before and after political literacy socialization. Samples were chosen by the accidental sampling technique. Accidental sampling is also known as sampling opportunity, convenience sampling, or free sampling. Accidental sampling is a nonprobability sampling technique in which subjects are chosen because of their convenient accessibility and proximity to researchers. The samples taken are 99 high school students in Semarang City, which represents the total number of respondents. The samples taken are the high school students which active in social media and does not escape political issues - potentially also becomes a beginner voter for political parties.

\section{RESULT AND DISCUSSION}

Based on Figure 1, the results showed that the majority of respondents viewed politics as government and power (49\%) had a sense of politics as government and power. As many as $35 \%$ of respondents interpreted politics as the strategy and how to realize the public interest, $10 \%$ interpreted politics as a political party and elections, and $6 \%$ interpreted politics as the seizure of position. The perspective of politics as a power, a party, a struggle for a position shows that respondents' perceptions towards politics are not fairly positive. Only $35 \%$ of respondents view politics as positive - the strategy and how to realize the public interest. This view emerged before the socialization of political literacy. 


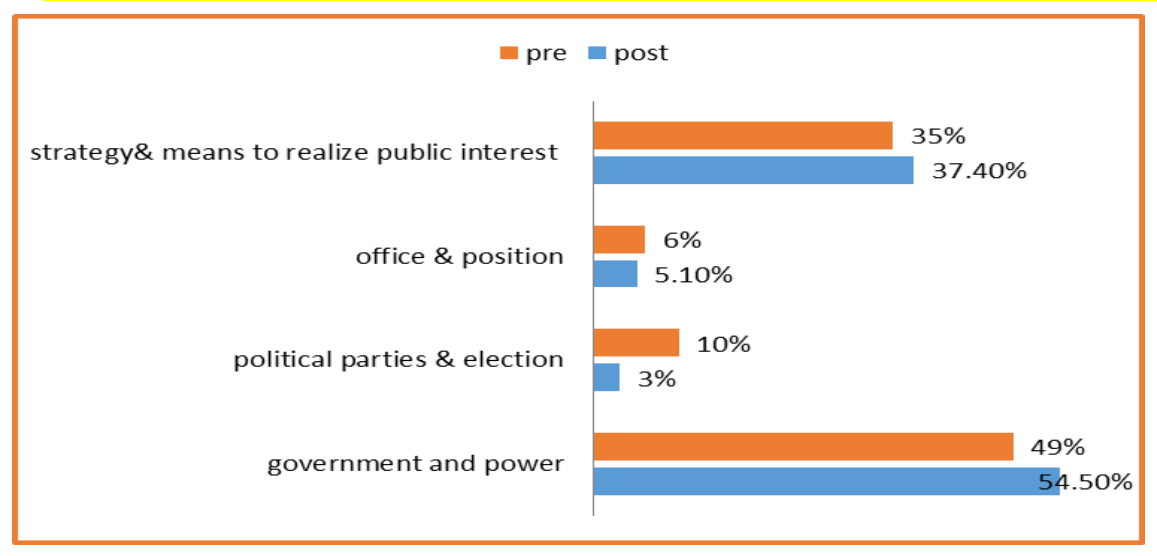

Figure 1.Youthizen's Perception of Politics

Source: Processed Primary Data, 2018

After the socialization, respondents experienced a shift of perception on politics. As many as $54.5 \%$ of respondents interpreted the politics as government and power, $37.4 \%$ interpreted politics as the strategy and how to realize the public interest, 5.1\% consider it as a struggle for positions, and as many as $3 \%$ consider politics as a political party and elections. Although insignificant, there is an increase in positive perceptions of politics is the respondents who consider politics as a strategy and how to realize the public interest. This suggests that the best way to change the understanding is by direct socialization of the target. These findings will consistently impact on other changes in respondents.

As seen in Figure 2, respondents rated political literacy as an effort to awaken people to aware and participate in politics (40\%), political-related activities (28\%), education to understand and care about politics (20\%), intellectual activity and efforts to make people literate on politics $(12 \%)$.

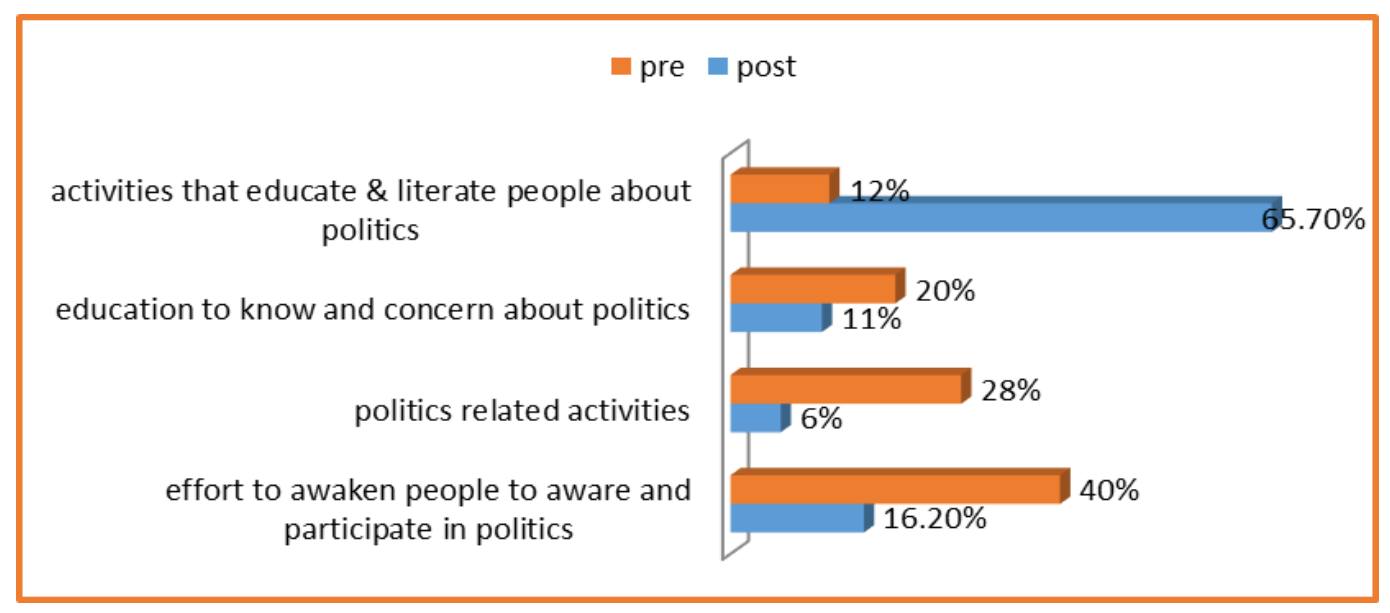

Figure 2. The Definition of Political Literacy According to Respondents Source: Processed Primary Data, 2018 


\section{Jurnal Ilmu Sosial Volume 19 | Issue 1| June 2020 | Page 22-39}

After the socialization, the views of respondents, in general, have changed. A total of $65.7 \%$ of respondents view political literacy as an activity to make people literate and intelligent about politics. About $16.2 \%$ of respondents view political literacy as an effort to make people aware and participate in politics. As many as $11.1 \%$ view political literacy as education to know and care about politics. Finally, as many as $6.1 \%$ of respondents view political literacy as activities related to politics and power.

There is a significant change in the definition of political literacy, according to respondents. Political literacy as an activity of educating and getting people literate on politics rose significantly from $12 \%$ to $65.7 \%$ of respondents. This means that effective socialization changes the respondents' knowledge of political literacy.

The above questions only indicate the level of knowledge of respondents related to political literacy. In the socialization, however, respondents got material regarding the importance of political literacy, especially in the current digital era. The access to non-stop responders to the internet and active engagement of social media makes political literacy essential for Generation Z.

Before the socialization, the results showed that the majority of respondents rated the hoax as false information $(86 \%)$. As many as $11 \%$ of other respondents consider it as information without source, $2 \%$ entertaining information, and $1 \%$ as fact. Generally, we can see that, from the beginning, respondents have proper knowledge about the hoax; only $3 \%$ of respondents who answered incorrectly on the definition of the hoax. After socialization, $76.8 \%$ of respondents rated hoax as false information and the rest $23.2 \%$ view hoax as information without source. It shows that effective socialization changed the respondent's perception concerning hoax.

Hoax is a typical problem of web 2.0 phenomena based on user-generated content. Users can generate their types of content that appear in their social media. On social media, users are free to produce any content; targeting anyone without having to include verification either from the parties concerned or from relevant sources. In such a situation, other users become distant. Message recipients are the only filters; by selecting what is right and useful before saving it for themselves and sharing it to others. Features owned by social media such as sharing and resharing provide great opportunities for the emergence of hoaxes. The lack of awareness of Indonesian netizens on false information also triggers the development of hoax in the cyberspace. Hoaxes and fake news were produced systematically in political communication during the $2014^{\text {th }}$ Indonesia presidential election (Hasfi, Usmand, and Santosa 2017). Political hoaxes were spread massively all over social media in Indonesia (Perbawani and Anshari 2018). Hoaxes and fake news were generally produced and distributed strategically by two pseudonyms Twitter ac- 


\section{Jurnal Ilmu Sosial Volume 19 | Issue 1| June 2020 | Page 22-39}

counts@TrioMacan2000 and@pkspiyungan.@Triomacan2000, with its 700.000 followers, produced the fake news of 'Jokowi communist' and 'Jokowi Anthek China' about four months before the 2014 presidential election (Santosa, Hasfi, and Lukmantoro 2018). Social media have become vital for the spread of political propaganda in Indonesia. For example, the demonstrations rallies in the $2017^{\text {th }}$ governor election in Jakarta were mobilized through social media and messaging applications. Research also showed how Twitter played a role in opinion mobilization in Indonesia (Hasfi 2017). In $2019^{\text {th }}$ presidential election, Prabowo was assumed to support sharia law to be applied in Indonesia since he was supported by some Islamic hardliners group such as Hizbut Tahrir Indonesia and Front Pembela Islam (Islamic Defender Front Militia) (Facal 2019) who was one of the initiators of demonstrations rallies to depose Ahok.

Before socialization, a total of $98 \%$ of respondents assume that political hoaxes are false information that seeks to influence the public. As many as $2 \%$ of respondents assume that political hoaxes are activities related to politics and power. After the socialization, a total of $100 \%$ of respondents know that political hoaxes are false information that seeks to influence the public. From the beginning, the respondents had the proper knowledge regarding political hoax. Thus, when the socialization is done, there is only a $2 \%$ increase in respondents' correct understanding regarding the political hoax. However, the notion is not automatically consistent with the respondent's ability to identify hoaxes, either hoax in general or political hoaxes in particular.

As seen in Figure 3, before the socialization, a total of $69 \%$ of respondents disagreed to use social media to argue related to politics. As many as $18 \%$ agreed, $12 \%$ strongly disagreed, and $1 \%$ strongly agreed to use social media for political opinion. After the dissemination of socialization, the willingness of respondents to share political attitudes and views on social media is increased. As many as $47.5 \%$ agreed, and 3\% strongly agreed to share political views and attitudes on social media. $43.4 \%$ of respondents disagreed, and $6.1 \%$ strongly disagreed with sharing political attitudes and views on social media.

Changes in views related to political attitudes and views on social media show that socialization can change the attitudes of respondents. Respondents who initially disagreed with the majority, changed their attitudes to agree using social media as a means of political expression. Change of attitudes after the socialization is quite significant compared to the attitude before socialization. The dissemination of social media in Generation $\mathrm{Z}$ life indicates that Generation $\mathrm{Z}$ will share the moments they consider important and meaningful in their daily lives to social media. Daily life with family, relatives, and friends, their hobbies, things they care about for their social media are among them. The attempts to keep a clean timeline from politics show the lack of interest and concern of the Generation $\mathrm{Z}$ respondents towards politics. 


\section{Jurnal Ilmu Sosial Volume 19 | Issue $1 \mid$ June 2020 | Page 22-39}

After socialization, the attitudes showed that Generation $\mathrm{Z}$ has greater potential to share political expression in social media than ever before. In research before socialization, Generation $\mathrm{Z}$ tends to keep their social media timeline clear of political issues, either from themselves or from their networks on social media (Lailiyah, Yuliyanto, and Pradhana 2018). They prefer to discuss politics in everyday life with their families (63\%). Political chats with the family take place in the real world. Aside from families, as many as $44 \%$ of respondents also admitted that friends also became their partners in political discussions. However, a political chat with a friend tends to happen in the real world. The reluctance to talk about political expressions and opinions in social media shows a lack of respondent's concern for politics. This becomes an issue in the context of democracy sustainability, both presently and in the future. A robust political system requires the attention of all of its constituents to engage either directly into political partisanship or by becoming a watchdog in the political game.

Another aspect that makes the willingness of respondents in sharing political expressions and views on social media important is because respondents consider the information circulating in social media in making decisions. As many as $73 \%$ of respondents agreed, and $8 \%$ strongly agreed that information in social media is considered in decision making. Only $16 \%$ of respondents disagreed, and 3\% strongly disagreed that information in social media considered in decision making. These findings showed the importance of social media for Generation $\mathrm{Z}$ respondents. Therefore, when political issues are not involved in social media, it shows that politics is a lack of importance for Generation $\mathrm{Z}$.

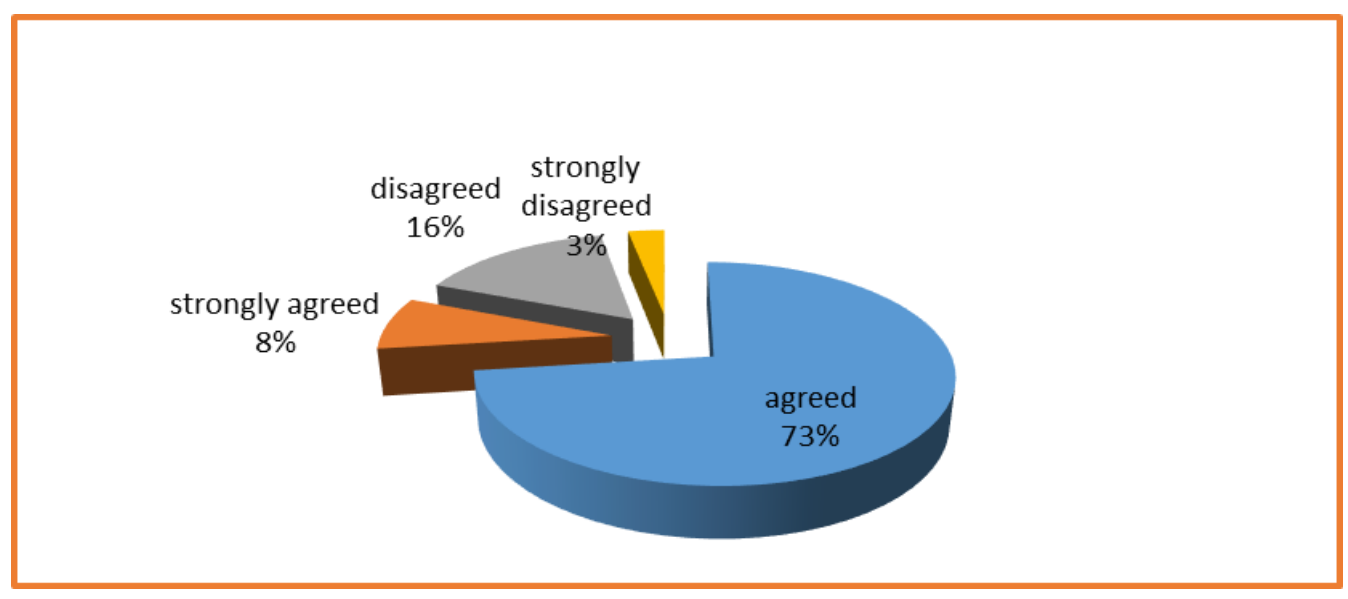

Figure 3. Respondents Consider the Information Circulating in Social Media in Making Decisions

Source: Processed Primary Data, 2018 


\section{Jurnal Ilmu Sosial Volume 19 | Issue 1| June 2020 | Page 22-39}

Nevertheless, in their capacity as beginner voters in the elections, Generation Z is often targeted by politicians. Beginner voters are considered vital since their young age and the minimal participation experience in voting is a combination that makes it easier to participate compared to other voter categories.

In the previous research, researchers found that political literacy consists of several levels of cognition, affection, and behaviour. The level of cognition shows the level of one's knowledge regarding the issues and political events around them. The level of affection indicates a person's concern and interest in the surrounding political issues and events. Behaviour levels indicate the level of one's involvement in the issue and the surrounding political events. Political issues and events are not merely based on political campaigns or elections, but also the government's policies (Lailiyah, Yuliyanto, and Pradhana 2018).

Based on Figure 4, the results showed that only $31 \%$ of respondents agreed and $2 \%$ of respondents strongly agreed that they are pro-actively seeking political information on social media. As many as $54 \%$ of respondents disagreed, and $13 \%$ of respondents strongly disagreed that they are pro-actively seeking political information on social media. We can see the behaviour of respondents that lead to political literacy. In this case, they are only a small percentage of those concerned about political issues. The behaviour indicates interest in politics ideally balanced with awareness or political literacy. Generation $\mathrm{Z}$ that depend on social media also needs to understand that it contains subjective views from the owner of the account and also vulnerable to hoaxes.

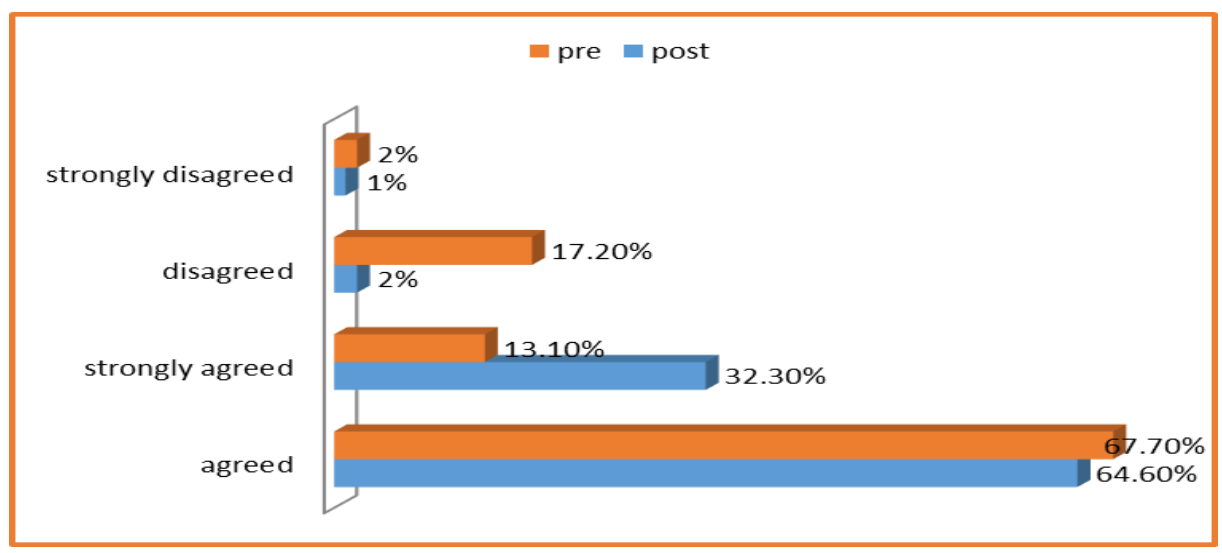

Figure 4. Respondents Checking the Accuracy of Information Before Sharing it to Social Media Source: Processed Primary Data, 2018 


\section{Jurnal Ilmu Sosial Volume 19 | Issue $1 \mid$ June 2020 | Page 22-39}

Before socialization, a total of $67.7 \%$ of respondents agreed, as $13.1 \%$ strongly agreed, 17.2 disagreed, and as many as $2 \%$ strongly disagreed with checking the accuracy of information before sharing it to social media. After socialization, a total of $32.3 \%$ of respondents strongly agreed, $64.6 \%$ agreed, $2 \%$ disagreed, and as many as $1 \%$ strongly disagreed with checking the accuracy of information before sharing it to social media. These findings show that socialization is effective in improving the alertness of respondents in sharing information to social media.

Aside from checking the accuracy of the information, social media users need to check the benefits of information before sharing it to social media. The information might be accurate, but if sharing it can cause conflict in the community, such information should be kept for ourselves. In the context of political information, we can easily find information on social media that needs to be verified - both the truth and the benefits. Notably, in political contestation such as elections.

Before socialization, a total of $64.6 \%$ of respondents agreed to check the benefits of information before sharing it into social media. 19.2\% disagreed, and 16.2\% strongly agreed to check the benefits of information before sharing it to social media. After the socialization, the respondent's perception changed. As seen in figure 5, a total of $26.3 \%$ of respondents strongly agreed, $68.7 \%$ of agreed, $4 \%$ disagreed, and as many as $1 \%$ strongly disagreed with checking the benefits of information before sharing it to social media.

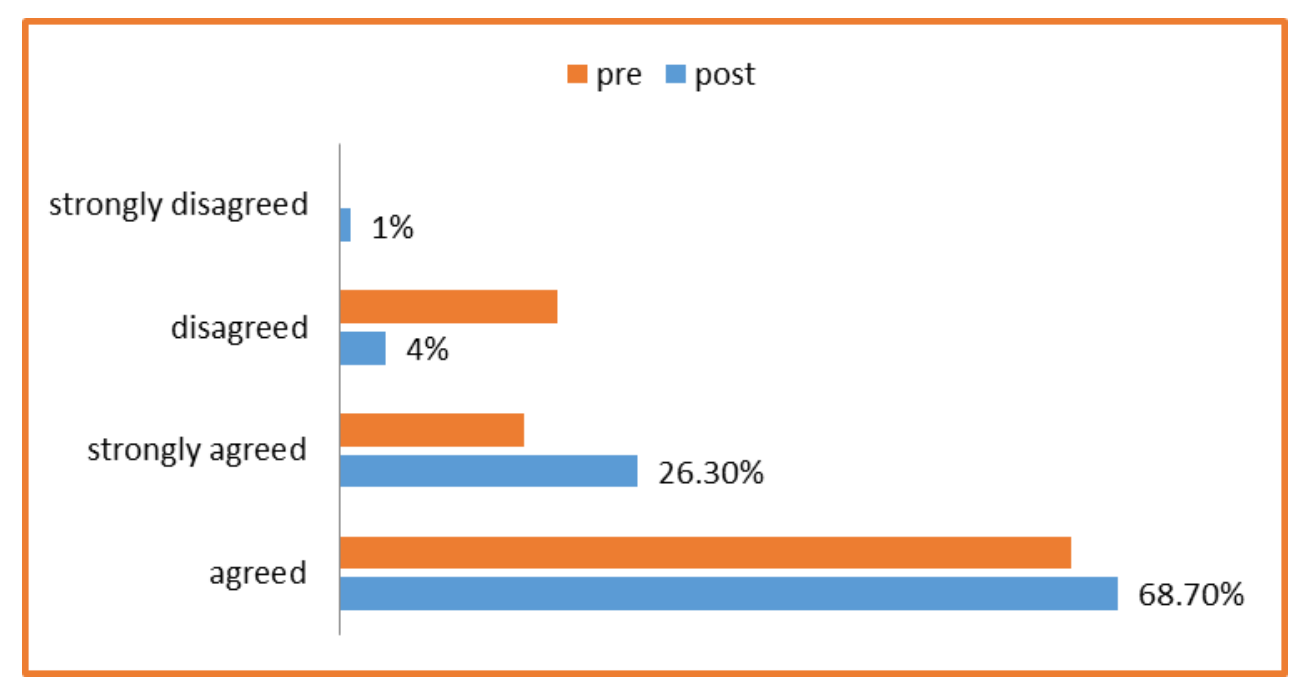

Figure 5. Respondents Check the Benefit of Information Before Sharing it to Social Media Source: Processed Primary Data, 2018

Before socialization, a total of $15.2 \%$ of respondents strongly agreed, $66.7 \%$ agreed, $17.2 \%$ disagreed, and as many as $1 \%$ strongly disagreed with checking the truth and benefits of 


\section{Jurnal Ilmu Sosial Volume 19 | Issue 1| June 2020 | Page 22-39}

information before sharing it to social media. These results indicate that the majority of respondents recheck the benefits as well as the accuracy of information before sharing it into social media. This is a positive thing. After the socialization, $29.3 \%$ of respondents strongly agreed to check the truth and benefits of information before sharing it to social media. As many as $5.1 \%$ disagreed, and $1 \%$ strongly disagreed with checking the truth and benefits of information before sharing it into social media. After socialization, a decrease in the percentage of respondents who disagreed to check the truth and benefits of information before sharing it into social media. Nevertheless, not all respondents agreed to do so. We can see that the socialization for two hours can give a significant change to the respondents.

The research resulted from data that were taken before the socialization showed that most respondents $(62.6 \%)$ agreed that the political information appeared on their social media timeline. They showed that there was political information that was shown repeatedly. Most respondents also agreed $(54.6 \%)$ that they read the whole information every time it is shown on their timeline. $65.1 \%$ of respondents disagreed with reading political comment and status on their timeline. Most of them agreed that there was a distraction while absorbing political information in social media. A total of $58.6 \%$ of respondents agreed that they were used to accept political information and messages on their social media. As many as $65.6 \%$ of respondents disagreed that they concern about political issues. About $67.7 \%$ of respondents agreed that they were used to do critical thinking in any context. Meanwhile, only $46.5 \%$ of respondents agreed that their environment considers them as critical persons.

About $85.9 \%$ of respondents believe political messages and information from their trusted sources. As many as $56.6 \%$ of respondents agreed that their mood affected the way they respond to political news. Furthermore, 59.6\% of respondents agreed that the more arguments enriched the political messages, news, or information, the more they were convinced by it. Only $36.4 \%$ of respondents attracted to political themes in social media. These findings showed that youth are less enthusiastic about politics. Meanwhile, $71.7 \%$ of respondents agreed to evaluate the quality of political messages and information on their social media. $78.8 \%$ of them evaluate political messages in social media scrupulously. As many as $75.8 \%$ of respondents evaluate the quality of political messages based on the quality of the source.

Based on Figure 6, the findings showed that most of the respondents did not seem interested in political issues on social media, but when it passed their social media timeline, they will evaluate the messages carefully. The results found that they used both peripheral and central routes in processing political issues and information. Previous research showed (Lailiyah, 2011) 


\section{Jurnal Ilmu Sosial Volume 19 | Issue $1 \mid$ June 2020 | Page 22-39}

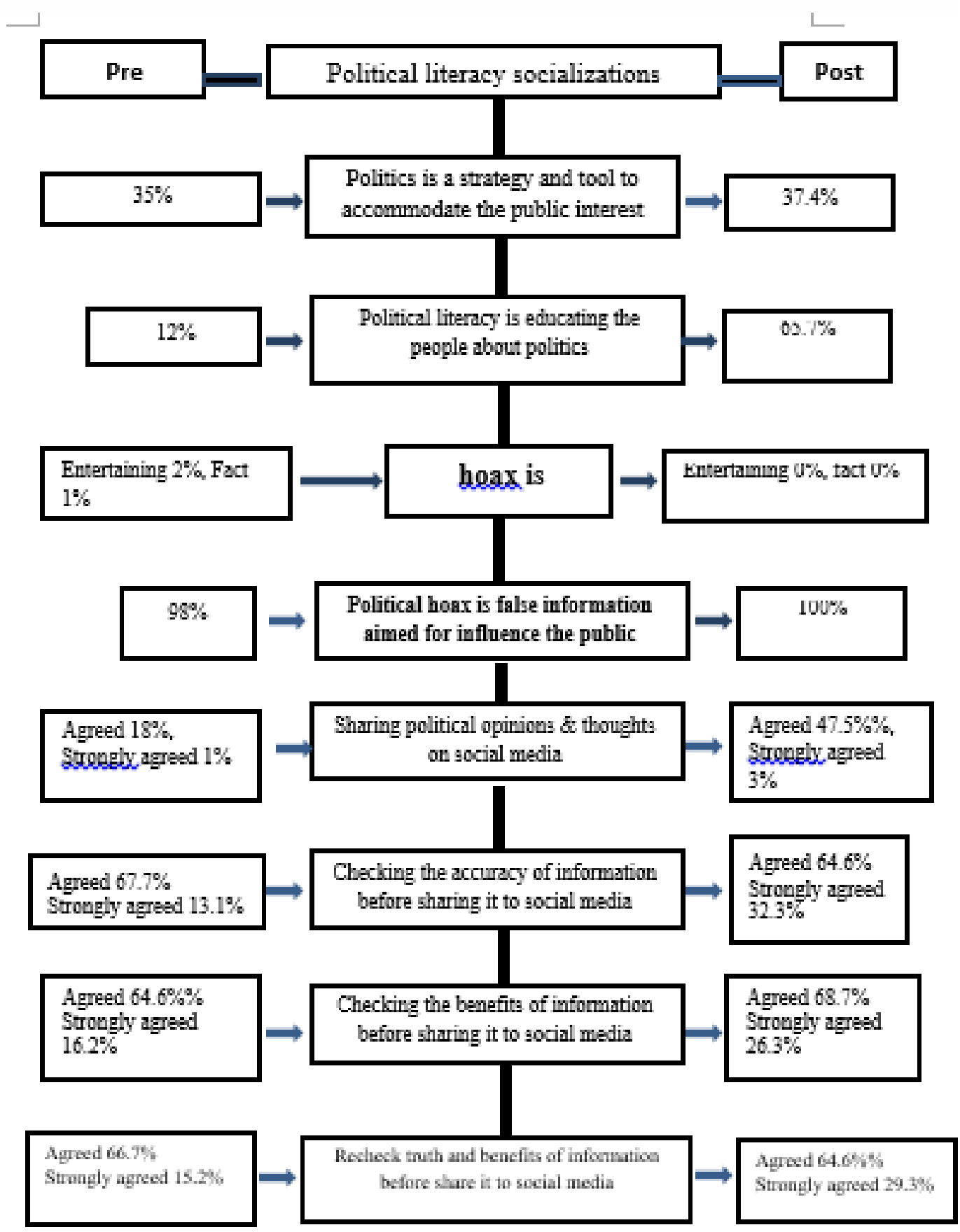

Figure 6. The Effects of Political Literacy Socialization to Generation Z Source: Processed Primary Data, 2018

that the combination of both central and peripheral routes in processing persuasive information would lead to a strong yet emotional attitude. 


\section{Jurnal Ilmu Sosial Volume 19 | Issue $1 \mid$ June 2020 | Page 22-39}

\section{CONCLUSION}

Educating Generation $\mathrm{Z}$ through direct socialization is effective in raising youthizen awareness of political literacy. For example, political socialization in elections is essential to support its success. Particularly, to suppress the number of abstentions and provide social means or norms to conduct black campaigns. Just as electoral political socialization by the Election Commission has been temporarily effective for the abstentions number when the category of community participation. Socialization directly contributes to changes in several cases, among others: change of respondent interpretation concerning politics, change of respondent interpretation concerning political literacy, change of respondent interpretation concerning hoax, change of respondent interpretation concerning political hoax, change of respondent attitude concerning willingness to share attitude and political opinion in social media, change of attitudes on checking the truth before sharing the information to social media, change of attitudes on checking the benefits of information before sharing it on social media and changing of attitudes on checking the benefits and truth before sharing the information to social media. The study concludes that socialization can improve the quality of political literacy of Generation Z.

\section{ACKNOWLEDGEMENT}

Heartfelt thanks and appreciation to the Faculty of Social and Political Sciences Universitas Diponegoro who funded this research. Data collection and processing were carried out independently by the research team.

\section{BIBLIOGRAPHY}

Ayun, Primada Qurrota. (2016). Penggunaan Instant Messenger dan Komunikasi Interpersonal Remaja. Jurnal Ilmu Sosial, 15(2): 111-20 (doi: 10.14710/jis.15.2.2016.111-120), [Online]

Bennet, S. \& Maton, K. (2010). Beyond the 'digital natives' debate: Towards a more nuanced understanding of students' technology experiences. Journal of Computer Assisted Learning, 26 (5): 321-331 (doi: 10.1111/j.1365-2729.2010.00360.x), [Online]

Biswas, Aindrila., Ingle, Nikhil., \& Roy, Mousumi. (2014). Influence of Social Media on Voting Behavior. Journal of Power, Politics \& Governance, 2(2): 127-155, [Online]

Facal, Gabriel. (2019). Islamic Defenders Front Militia (Front Pembela Islam) and Its Impact on Growing Religious Intolerance in Indonesia. Trans-Regional and-National Studies of Southeast Asia, (January): 1-22 (doi: 10.1017/trn.2018.15), [Online] 


\section{Jurnal Ilmu Sosial Volume 19 | Issue 1| June 2020 | Page 22-39}

Hasfi, Nurul, Sunyoto Usmand, and Pudjo Santosa. (2017). Anonimitas Di Media Sosial: Sarana Kebebasan Berekspresi atau Patologi Demokrasi?. Jurnal Ilmu Komunikasi, $15 \quad$ (1): $\quad 28-38 \quad$ [online]. Retrieved from http://jurnal.upnyk.ac.id/index.php/komunikasi/article/view/2152 [Accessed May 20, 2018]

Howe, N. \& Nadler, R. (2012). WHY GENERATIONS MATTER: Ten Findings from Life Course Research on the Workforce [online]. Retrieved from https:// www.lifecourse.com/assets/files/Why\%20Generations\%20Matter\%20LifeCourse\% 20Associates\%20Feb202012.pdf [Accessed on 9 November 2017]

Lailiyah, Nuriyatul. (2016). Presentasi Diri Netizen dalam Konstruksi Identitas di Media Sosial dan Kehidupan Nyata. Jurnal Ilmu Sosial 15(2): 103-10 (doi: 10.14710/ jis. 15.2.2016.103-110 [Online]

Lailiyah, Nuriyatul, Much Yuliyanto, and Ghozian Aulia Pradhana. (2018). Youthizen, Political Literacy, and Social Media. In E3S Web of Conferences73, 14005 ICENIS 2018, EDP Sciences, 20-23 (doi:10.1051/e3sconf/20187314005), [Online]

Littlejohn, Stephen W \& Karen Foss. (2008). Theories of Human Communication (9th Ed.). Bellmont, California: Wadsworth

Mowen, John C. \& Michael Minor. (2002). Perilaku Konsumen Jilid I. Jakarta: Penerbit Erlangga

O' Keefe, D. J. (2009). Theories of Persuasion. in Oliver, M. B. \& R. Nabi (Eds.). (2009), Handbook of media effects. California: Sage Publications.

O'Keefe, D.J. (2008). Elaboration Likelihood Model. In Donsbach, Wolfgang (Ed). International encyclopedia of communication Vol IV.Oxford: Blackwell Publishing

Perbawani, Pulung S, and Irham N Anshari. (2018). Online Political Participation and Netizen Anonymity In Indonesia's Digital Democracy. Journal Power Conflict Democracy. 6(2): 185-212 (doi:10.22146/pcd.41905), [Online]

Santosa, Hedi Pudjo, Nurul Hasfi, and Triyono Lukmantoro. (2018). Digital Media Unequality during the 2014th Indonesian Presidential Election. In proceeding E3S Web Conf. Volume 73, 2018. The 3rd International Conference on Energy, Environmental and Information System (doi:10.1051e3sconf/20187314006), [Online] 